\title{
TRADE AND WAGES: INSIGHTS FROM THE CRYSTAL BALL
}

Robert Z. Lawrence

Carolyn L. Evans

Working Paper 5633

\section{NATIONAL BUREAU OF ECONOMIC RESEARCH 1050 Massachusetts Avenue \\ Cambridge, MA 02138 June 1996}

We thank participants in seminars at Harvard University, the University of Michigan and the OECD for comments and suggestions and Howard Shatz for providing us with data. Robert Lawrence acknowledges support from NASDAQ, the OECD Development Center and the US Department of Labor/LAB. Much of this paper reflects work done for the study Single World, Divided Nations? to be published by the Brookings Institution for the OECD Development Center. This paper is part of NBER's research program in International Trade and Investment. Any opinions expressed are those of the authors and not those of the National Bureau of Economic Research.

(C) 1996 by Robert Z. Lawrence and Carolyn L. Evans. All rights reserved. Short sections of text, not to exceed two paragraphs, may be quoted without explicit permission provided that full credit, including (C) notice, is given to the source. 


\title{
TRADE AND WAGES: INSIGHTS FROM \\ THE CRYSTAL BALL
}

\begin{abstract}
This study uses both a net factor content analysis and a small simulation model to explore the impact on the U.S. labor market of a fivefold increase in imports of manufactured goods from developing countries. The simulation, which is parameterized by the US economy in 1990 , involves a balanced trade expansion which displaces almost half of US manufacturing workers who are reemployed in the remaining manufacturing and non-trade sectors. The results show that relative wages of workers with a high school education or less would be depressed, while those with some college education would rise. However, despite the magnitude of the shock, the effects are surprisingly small. Once account is taken of productivity increases, labor force growth and export sector wage premiums, given unitary elasticities of demand and of substitution between workers with different levels of education, relative wages of workers with some college education rise by 3.5 percent, while the real wages of workers with a high school education or less decline by 1.3 percent. The impact of a variety of parameter assumptions is also explored.
\end{abstract}

Robert Z. Lawrence

Center for Business and Government

John F. Kennedy School of Government

Harvard University

79 JFK Street

Cambridge, MA 02138

and NBER
Carolyn L. Evans

Department of Economics

Harvard University

Cambridge, MA 02138 


\title{
Trade and Wages: Insights from the Crystal Ball.'
}

\author{
Robert Z. Lawrence, Harvard University and \\ Carolyn L. Evans, Department of Economics, Harvard University. \\ June 1996.
}

\section{Part I: Introduction}

Since the late 1970s, the United States labor market has experienced a slow rise in average compensation and growing inequality along lines of skill, education, and occupation. Between 1979 and 1990 , for example, the weekly earnings for full-time workers with some college education increased $17 \%$ more rapidly than the earnings of workers with a high-school education or less. As measured by the employment cost index, between 1981 and 1991 the relative compensation of blue-collar workers compared with white-collar workers outside of sales declined by 12 percent. While there is evidence that in the 1990s the trends towards increased inequality has slowed (Bound and Johnson (1995)) or even ceased, (See Figure 1) the debate over the sources of inequality continues to rage. ${ }^{2}$

${ }^{1}$ We thank participants in seminars at Harvard University, the University of Michigan and the OECD for comments and suggestions and Howard Shatz for providing us with data. Robert Lawrence acknowledges support from NASDAQ, the OECD Development Center and the US Department of Labor/ILAB. Much of this paper reflects work done for the study Single World. Divided Nations? to be published by the Brookings Institution for the OECD Development Centre.

${ }^{2}$ See for example, Borjas, Freeman, and Katz (1992), Lawrence and Slaughter (1993), Sachs and Shatz (1994), Wood (1994), Baldwin and Cain (1994), Cooper (1994), Krueger (1995), and Leamer (1995). 
Most recent studies of the links between trade and wages have looked backwards, considering the impact of trade on the labor market over the past two decades. But the rapid increase in US trade with developing countries over this period can be expected to continue into the future. Indeed, the pace and volume could grow dramatically if India joins China and other Asian countries in successful export-led growth. It is this specter of billions of new lowwage workers being drawn into the labor market, which has led many in the popular press to predict a bleak future for low-wage workers in the developed countries. (Goldsmith 1993) In this paper, we therefore construct a scenario which allows us to study the impact of a very large increase in such trade.

We will present evidence which suggests that while growing international trade between the United States and developing countries could lead to lower relative and real wages for unskilled workers, the fears of large absolute and relative wage losses for less-skilled workers appear misplaced. If sustained over the next fifteen years, an expansion in trade between the US and the developing countries at the double-digit pace of the past decade would bring about a major change in the structure of US manufacturing production. In particular, the US could see a decline in large segments of its basic industrial activities as these are replaced by imports from emerging markets. However, matching this decline will be an expansion of skill intensive activities that will provide an offsetting source of growth.

We find that while trade could effect major shifts in the structure of US production, its impact on the wage structure is unlikely to be large. ${ }^{3}$ The basic reason for this small impact is

${ }^{3}$ This analysis draws on Lawrence (1996). 
that manufacturing in general, and those sectors potentially vulnerable to developing country competition in particular, comprise a relatively small share of total employment. Once the US economy is driven to specialize fully in skill-intensive products, trade no longer widens the relative wage gap.

The factor price equalization theorem leads some to predict that free trade with developing countries will drive the wages of unskilled US workers down to Chinese or Indian levels. But the theorem only holds under conditions of incomplete specialization. Once countries become fully specialized, the strong links between international wages and product prices break down. For example, if a country has no domestic production of clothing, imports of clothing will no longer directly affect wages. One way for firms in developed economies to avoid head-to-head competition with developing countries, therefore, is to specialize in producing products which are not imported from developing countries. Under these conditions, wages and other factor prices in the developed countries will be determined only by the goods and services that they actually produce: namely, those that are exported and those that are not traded. Put more simply, the floor on the wages of unskilled workers in the developed countries is not what workers earn in the textile industries of China and India, but what they can earn if they are employed in export and domestic industries. It is this floor which we seek to estimate.

\section{Part II: The Experiment}

The type of shock we are considering can be illustrated in Figure 2 which illustrates the production possibilities frontier of the traded goods sector. The US starts from a position of 
autarky; ${ }^{4}$ trade with developing countries then expands until the economy becomes fully specialized, moving outside the zone of diversification to a corner solution in which only exportables are produced. Note that our shock arises purely from "trade", i.e. it represents changes in the trading opportunities presented to us by the rest of the world. Technology, tastes, and factor supplies, all of which potentially influence trade volumes, are held constant throughout.

\section{The Net Factor Content Approach}

Since some economists have been extremely critical of the net-factor content approach on which we will partly rely it is important that we explain our methodological choice. In particular, Bhagwati and Dehejia (1994), Lawrence and Slaughter (1993), and Leamer (1995) have all emphasized that trade volumes might not be good indicators of trade pressures. Indeed, one can think of examples in which just the threat of increased imports could drive domestic wages down without leading to increased trade flows. These authors therefore prefer paying attention to price evidence. If trade lowered the relative wages of unskilled workers, we would also expect to see a decline in the relative prices of goods which are produced using unskilled labor relatively intensively.

But as pointed out by Deardorff and Staiger (1988) and more recently by Krugman (1995) and Leamer (1996), the net factor content approach is useful and not inconsistent with a consideration of prices provided the investigation is considering a fairly precise question. In

${ }^{4}$ The initial autarkic point is used to provide benchmark prices at which the economy initially trades. 
particular, the approach can be used to study the impact on relative factor prices of a particular change in trading opportunities, for example, the impact of imposing prohibitive trade barriers. $^{5}$ Moreover, in a log-linear economy, with Cobb-Douglas utility and production functions, the net factor content calculations have an appealing feature because changes in the net factor content of trade as a proportion of total factor supplies give rise to proportional changes in relative factor prices.

The major problem in applying this approach empirically to explain historical episodes is that it requires assuming that the trade flows actually observed were caused only by the change in the trading opportunities available and not by other changes such as technology, tastes and relative factor supplies, which might also be expected to influence such flows. In practice, this assumption will not hold, and it is not easy to identify these effects separately because they are interactive. Changes in demand, factor supplies, technology, and opportunities to trade internationally could all affect the composition of trade, output, and relative product and factor prices. In particular, as Deardorff and Hakura (1994) have emphasized, the volume of trade is an endogenous variable which is simultaneously determined with wages. If trade is generated by a decline in trade barriers at home or abroad the impacts on wages could be very different than if trade is generated by changes in tastes or technology.

The studies of trade in the past all suffer from the problem of isolating the effects of trade precisely. In a recent article, Leamer (1996) claims that because of the problems we have just

${ }^{5}$ The reason, as Deardorff and Staiger (1988) show, is that any given trade equilibrium can be associated with an equivalent autarky equilibrium in which factor endowments are changed by the amounts of the factor content of trade. "Since factor prices in autarky are related to factor endowments, it follows that factor prices with trade are related to its factor content." 
discussed the net factor content approach is of extremely limited use. ${ }^{6}$ Leamer emphasizes that the net factor content approach can (only) be used to compare two equilibria that have the same tastes, technologies, and factor supplies and that differ only in terms of external trading opportunities. But accepting these restrictions, the net factor content approach is actually a useful starting point for studying the shock we are interested in this paper, namely a dramatic future expansion in America's opportunities to trade. Moreover, because we can set up a precise experiment, we can actually learn about the past by looking at the future.

\section{The Experiment}

Let us explore the implications of a very large expansion in U.S. manufactured goods trade using data on the US economy in 1990. We obtain an upper bound impact on the US labor market by assuming that industries which compete with manufactured imports from developing countries are totally eliminated. The US shifts into non-competing industries, and workers find jobs in sectors producing exports or non-traded goods and services.

High-skill and basic industries. Which industries are potentially most vulnerable to competition from developing countries? Table 1 lists US industries ranked according to the share of full time workers with a high school education or less-- "high-school workers" -- in the labor force in $1990 .^{7}$ The industries range from Tobacco, in which high school workers accounted for just 43 percent of employment, to Apparel in which they constituted 85 percent.

\footnotetext{
${ }^{6}$ The analysis using prices encounters the same problems.

${ }^{7}$ Industry SIC 29, petroleum refining, has been excluded.
} 
The industries seem to fall into two distinct groups. There is one group of seven industries in which high-school employment shares range from 43 to 53 percent and a second group with shares ranging between 65 and 85 percent. There are no two digit industries between 53 and 65 percent. This suggests a natural division. The first group, we define as "high-skill" industries. It includes printing and tobacco plus the industries that are usually classified as "high-tech" namely chemicals, machinery and instruments. The second group, which we define as "basic," includes all other manufacturing industries.

Clearly, given the level of aggregation, this is a fairly crude approximation, but it does have quite strong predictive value with respect to trade with developing countries. The highskill industries accounted for about three quarters of all US manufactured exports to developing countries, while the basic industries accounted for almost sixty percent of US manufactured imports from developing countries. Moreover, exports to developing countries count for much higher shares of value added in the high-skill industries (11 percent) than in the basic industries ( 5 percent). On the other hand, the ratio of manufactured imports to domestic value-added is much higher for low skill (15 percent) than for high-skill (8 percent).

Scenario. This classification of US industries suggests an extreme scenario in which the US becomes fully specialized in high-skill products. In this scenario, as reported in Table 2 , the US completely replaces the 1990 domestic value-added of $\$ 552$ billion which was produced in these basic industries with imports from developing countries. In turn, exports (and production) of the high-skill industries expand by an additional $\$ 552$ billion in proportion to their 1990 output shares. This is clearly a very dramatic scenario. In 1990, US imports from developing countries of manufactured goods amounted to $\$ 140$ billion. In the alternative 
scenario they are assumed to increase to $\$ 690$ billion -- in other words, there is a five-fold increase. If this increase took place over a fifteen year period it would correspond to an annual growth rate of 11.3 percent. These effects would build up over time and become larger in later years when trade volumes are larger. After 10 years, only about half of the effects would be felt.

As reported in Table 2, given constant ratios of inputs to outputs, this switch eliminates the demand for the 8.7 million workers employed in basic industries (6.4 million high-school workers and 2.3 million college workers.) On the other hand, the increase in value-added of the high-skill manufacturing sector by $\$ 552$ billion raises demand for 7.6 million workers split evenly between high-school and college workers. All told therefore, this substitution results in an excess supply of 2.6 million high school workers and an excess demand for 1.5 million college workers. Given this alternative production structure for manufacturing, with no change in relative wages, the demanded economy-wide employment ratio of high-school to college workers is 88.2 percent. In fact, in 1990, the supply ratio of these workers was 95.4 percent. Thus as compared to 1990, the relative demand for high school workers would decline by 7.5 percent. To clear the labor market, therefore, the relative wage of high-school workers would have to fall to encourage firms in both high-skill manufacturing and the nonmanufacturing economy to hire more high-school and fewer college workers. A key question, therefore, is the sensitivity of the relative demand for different types of workers to relative wages -- the elasticity of substitution. The literature provides a wide range of estimates. ${ }^{8}$ If

\footnotetext{
${ }^{8}$ For a survey see Hamermesh (1986).
} 
we assume this elasticity is unity, we obtain a proportional decline in the relative wages of high-school workers i.e. 7.5 percent. ${ }^{9}$

Product Price and Real Wage Changes. Thus far the analysis has estimated the impact of trade on relative wages. We know however, from trade theory, that in this scenario the real wage of skilled workers will rise and the real wage of unskilled workers will fall. To obtain explicit relative price and real wage effects associated with this scenario, we now simulate the scenario with a general equilibrium, two-factor, three sector model calibrated on 1990 US data. Appendix I contains a more detailed description of the model.

Description of Model. The model has a non-traded goods sector which accounts for 83 percent of consumption and high-skill and basic manufacturing industries which account for 10 and 7 percent respectively. The sectors turn out to be roughly mirror images. In basic manufacturing, unskilled labor receives 62 percent of income, whereas in high-skill manufacturing its share is 37 percent. Initially, the model has Cobb-Douglas production and consumption functions and is parameterized using the data in Table 1. The parameterization is very close to, but not precisely the same as the net factor content scenario for computational reasons.

Tables 3 to 5 describe some important parameters of the model and the simulation results. The first striking feature of the model is the flatness of the production function, confirming a result noted by Johnson (1966) many years ago. A decline in the relative price of basic

${ }^{9}$ Deardorff and Staiger (1988) show that if product expenditures and factor shares remain constant shares of income, the change in relative wages will be proportional to the changes in total relative factor supplies represented by changes in the net factor content of trade. 
manufactures of just 1.8 percent suffices to drive the economy to complete specialization. (See Table 3) This reemphasizes the importance of the magnification effect -- i.e. that relatively small changes in prices can have fairly large effects on relative wages. The real wages of high-school workers fall by 4.4 percent, while the real wages of college workers rise by 2.9 percent, leading to about the same relative wage shift as obtained in the net factor content calculations.

It is noteworthy that while the effects of trade on the distribution of income are substantial, the impact on real income is small -- this might be expected given the $7 \%$ share of basic manufactures in consumption and the decline in relative import prices under two percent. Indeed, overall real income in the economy rises by just one twentieth of one percent.

\section{Qualifications}

Elasticity Parameters. In Table 3, we also explore the sensitivity of our results to alternative estimates. ${ }^{10}$ As reported, a lower elasticity of substitution in consumption (of 0.5 ) does not lead to major changes in the results. This gives rise to a slightly larger relative price effect ( -2.0 percent) and a fall in relative unskilled wages by 7.6 percent, divided between a decline in real high-school wages of 4.7 percent and an increase in college wages of 3.2 percent. By contrast, lowering the elasticity of substitution in production to 0.5 does have a considerable impact, leading to changes in relative prices of 4.1 percent and relative wages of 14.9 percent split between a decline in real wages of high-school workers by 9.1 percent and

\footnotetext{
${ }^{10}$ Note that these simulations use CES production and utility functions.
} 
an increase in real college wages by 6.9 percent.

The literature is divided on which parameter is appropriate. Katz and Murphy (1992) in a aggregative estimate obtain an elasticity of 1.41. Sachs and Shatz (1995) by contrast argue for parameters of between 0.3 and 0.5 . ${ }^{11}$ In his survey Hamermesh (1986) gives a wide range of estimates. When these are estimated using cost functions they range between zero and 3.7 with a mean of about unity. As Adrian Wood points out econometric estimates of the elasticity of substitution probably capture not only the pure factor substitution effect in producing a given product but also the effects induced by different factor prices on product mix and quality. ${ }^{12}$ Wood argues this is a problem for the simulation he wishes to perform and therefore uses lower estimates to capture only the substitution possibilities in producing a specific bundle of goods. However, for our purposes, the induced effects are also relevant since they would come into play in response to changes in relative factor prices in response to trade and thus moderate the impact of trade on factor prices. This leads us to conclude that estimates of the elasticity in the range of unity appear reasonable, indeed could be conservative.

Growth. By using data from 1990 we ignored two important considerations that lead to an overstatement of these effects. First, we overlooked that over a fifteen year period, there will be productivity improvements. Indeed, over a fifteen year period, with output per worker in

${ }^{11}$ Note, if the elasticity of substitution is low it implies that the impact of both trade and skillbiased technical change will be larger for any given displacement of labor. For a more complete exploration see Lawrence and Evans (1996).

${ }^{12}$ For more discussion see Wood (1994), pp. 132-134. 
manufacturing increasing at the 2.5 percent annual rate it averaged between 1979 and 1994 , for example, the employment impact of these shifts would be reduced by 44 percent.

(Alternatively, we could think of these as scenarios in which developing country trade volumes could be larger by 44 percent to have the estimated effects.) Taking productivity growth into account, therefore, suggests that an 11.3 percent annual growth rate over fifteen years in imports from developing countries would reduce the relative demand for high school workers by $0.56 * 7.5=4.1$ percent in the case of a unitary elasticity of substitution and by 9.2 percent with an elasticity of substitution equal to 0.5 . This would imply declines in real highschool wages of between 2.5 and 6.2 percent. This is therefore a more realistic estimate of the displacement effects of the volume effects in the scenario.

Second, the US labor force is likely to grow over this period at an annual rate of around one percent. This implies that the employment shifts represented by these trade flows will represent relatively smaller shares of the labor force. Assuming a proportional increase in the ratio of high-school to college workers, this would reduce the estimates of relative wage changes implied by these trade volumes of an additional fifteen percent, i.e. to $.85 * 4.1=$ 3.5 percent with an elasticity of substitution equal to unity and 7.82 percent with an elasticity of substitution of .5 , yielding real wage declines for unskilled workers of between 2.1 and 5.3 percent, when we account for both growth and productivity changes. Actually since the supply of more educated workers will rise relatively rapidly these effects are likely to be even smaller.

Rents. The simulations have assumed that average wages earned by high-school and college workers are the same throughout the economy. But in fact, there are differences. Katz and 
Summers (1989) estimate these wage premiums for two-digit manufacturing for managers and laborers. Ascribing their estimates of rents for managers to college workers and for laborers to high-school workers suggests that on average the rents of managers and workers in basic industries are 6 and 2 percent respectively, while for college and high-school workers in high skill industries on average they are 15 and 13 percent Thus, given these rents, the shift in employment from the basic to the high skill sector would increase average rents for both types of workers. This would be the source of additional gains from trade. ${ }^{13}$ On average, for employment shifts laid out in the net factor content scenario described above, average economy-wide rents earned by high-school and college workers would rise by 0.7 and 0.8 of one percent respectively. Taking these into account therefore leaves the impact of trade on relative wages unchanged, but using the estimates which account for both productivity and labor force growth imply real wages declines of unskilled workers of 1.3 and 4.5 percent for elasticities of substitution of 1 and 0.5 respectively.

Induced demand and supply. We have taken the relative supplies and demands for these factors as given. But there are likely to be responses in both demand and supply which will reduce this effect. On the demand side, technological innovation could occur which saves on the use of college workers and makes more intensive use of high-school workers. On the supply side, the lower relative wage of high-school workers implies an increase in the return to education. If it induces workers and new labor force entrants to invest more in education, this will reduce the relative supply of high-school workers and bolster their relative wages.

${ }^{13}$ Indeed, Katz and Summers (1989) find that US export industries provide higher wage premiums than those competing with imports. 
Services Trade. This scenario should not be taken as an accurate forecast of the specific sectors that are likely to be affected by trade with manufacturing. Indeed it is likely that even in the face of increased imports of the size we have considered many of the basic industries will survive and some of the high-skill will not. However, the exercise should be seen as a parable which indicates orders of magnitude when unskill-- intensive sectors are displaced. Thus some of these could be in the services sector rather than manufacturing. There is, however, an important question of whether even these orders of magnitude are too small because improvements in communications could dramatically increased the scope of what may be traded. In particular, as an example in the low skill area, data processing activities once performed domestically in OECD countries are increasingly undertaken abroad. On the other hand, even high-skill firms are finding it feasible to use software and other talented engineers in developing countries. Nonetheless, if the experience in goods trade is indicative, it remains likely that services trade between OECD and developing countries will occur mainly along skill lines, with the OECD exporting skill-intensive services and importing unskilled-intensive services. The literature on the potential for providing long distance services has been surveyed by the World Bank (1995) $\cdot{ }^{14}$ It reports studies showing that an estimated 12 to 16 percent of employment in services in the G7 engage in services that could technically be provided at long distance. However, there are many activities that for strategic reasons, such as preserving proprietary information, companies are reluctant to outsource, particularly internationally. The Bank therefore estimates that between 1 and 5 percent of the total employment in services in

\footnotetext{
${ }^{14}$ World Bank (1995), Chapter 3.
} 
the G-7 economies are contestable internationally. This suggests a potential market for such exports in the US in 1990 dollars of between $\$ 14.4$ and $\$ 43.1$ billion, and in the G7 of between $\$ 40.3$ and $\$ 121$ billion. While the high estimate of $\$ 43.1$ billion represents about thirty percent of the value of US manufactured imports in 1990, if the internationally contestable share remained a similar proportion of employment over the next fifteen years, it would be too small to have a major impact on the calculations in this scenario. $\$ 43.1$ billion would represent an addition of only 7.8 percent to the volume of imports contemplated here. Apparently, therefore, the overwhelming majority of output outside of manufacturing will remain non-traded.

Aggregation. If the manufacturing sector was disaggregated further than we have done here, it is likely that somewhat larger estimates could be obtained since a finer division might lead to somewhat higher high-school to college ratios for those workers who are displaced and somewhat lower ratios for the jobs that are added in export industries. Stacking the industries using a three digit level of disaggregation we obtained estimates which led to impacts approximately 1.5 times as large as those obtained at the two-digit level. Similarly, the effects could be larger if we had disaggregated workers into more education categories. In particular, Borjas, Freeman and Katz (1992) find more powerful effects of immigration on the relative wages of workers with less than high-school education.

Japan. In the United States, as we have seen, manufactured trade is highly differentiated along the lines of skill that is captured by measures of education. Manufactured exports are concentrated in high-technology products with high ratios of college to high-school graduates, while imports, particularly those from developing countries, are concentrated in more basic 
industries in which skill ratios are low. Judged by educational attainment, Japan's patterns of industrial production and international specialization are much less distinctive than the US. The share of the labor force with a high-school education or less is much higher in Japan than in the US and the range of the ratios of high-school to college graduates across industries is much narrower. One reason could be a greater reliance on on-the-job training for skills development, but this is not the only reason. As estimated by Kosai in Thygesen, Kosai and Lawrence (1996), for example, the 78.1 percent share of high school workers in high-skill Japanese industries, which account for 82.3 percent of all Japanese manufactured goods to developing countries, is not very different from the $\mathbf{8 8 . 0}$ percent share in basic industries, which account for just 18 percent of such exports. Moreover manufactured imports from developing countries are split evenly between these two categories.

The result is that net factor content analysis shows balanced expansions of trade having much smaller effects on the relative demand for workers with different education levels. Indeed, eliminating all basic industries displaces 4.17 million high-school workers and 0.57 college workers, while replacing their value-added with output from the high-skill industries results in a demand for 3.39 high-school and 0.95 college. Overall, the economy wide ratio in the demand for high-school to college workers falls by just 2.03 percent -- an impact of less a third than in the US. This analysis helps explain why Japanese concerns are more focused on hollowing out than growing wage inequality. These concerns reflect the perception that imports from developing countries are challenging Japanese firms with fairly sophisticated skill levels. 


\section{Part III: Conclusions}

This exercise suggests that over a fifteen year period, rapid increases in US trade with developing countries could depress the relative and absolute wages of unskilled US workers. Given an increase in productivity and growth in the labor force, the decline in real wages would be about 2.5 percent. This effect would be mitigated by an additional 0.8 percent boost because of wage premiums in the export sector.

In an economy in which average real wage growth was fairly strong, this type of change, of between a sixth and a third of a percent a year, would not be a major issue -- particularly if there were other positive effects on the less skilled because of other changes in the labor market. If average real wages in the US were to rise by one percent per year due to higher domestic productivity, workers could absorb the change due to trade and still experience real earnings growth of between 0.84 and 0.67 percent annually.

It should be emphasized, moreover, that this is an upper bound impact. It ignores the fact that trade may bring benefits by increasing scale economies, enhancing competition, transferring technology and increasing product diversity -- all of which could raise wages of both high-school and college graduates. It also ignores the fact that poorer workers are more likely to consume the price-sensitive basic goods whose prices will fall a result of trade.

Moreover, once the economy eliminates domestic production of the basic industries in which the developing countries specializes, additional increases in world supplies of these products would increase the real wages of all American workers by providing them with 
cheaper imports. ${ }^{15}$ Additional trade with developing countries would then not necessarily affect wage inequality in the USA, although given the relatively small overall shares of imported goods in consumption this effect should not be exaggerated.

Finally, this simulation about the future also contains an implicit, but very important lesson about the past. If the impact of very large shifts in trade in the future is likely to be relatively small, it suggests that the much smaller growth in trade with developing countries over the past fifteen years is unlikely to have had the major impact on labor markets in the OECD which many claim it has.

15 If the developing countries shift into high-skill products, on the other hand, the US terms of trade could decline and wages in the US would become more equal. 


\section{References.}

Baldwin, R and Cain, G. 1994. "Trade and US Wages: Some Preliminary Results." NBER Working Paper.

Berck, Peter and Sydsæeter, Knut. 1993. Economists Mathematical Manual, Second Edition. Berlin: Springer-Verlag.

Berman, Eli, Bound, John, and Griliches, Zvi. 1993. Changes in the Demand for Skilled Labor within U.S. Manufacturing Industries: Evidence from the Annual Survey of Manufacturing. National Bureau of Economic Research Working Paper 4255. Cambridge, MA: National Bureau of Economic Research.

Berman, Eli, Bound, John, and Griliches, Zvi. 1994. "Changes in the Demand for Skilled Labor within U.S. Manufacturing Industries.” Quarterly Journal of Economics. 109(May): 367-97.

Bhagwati, J. and Dehejia, V. 1994. “Trade and the Wages of the Unskilled: Is Marx Striking Again?" in J. Bhagwati and M. Kosters, eds. Trade and Wages: Levelling Wages Down? Washington: American Enterprise Institute.

Borjas, G., Freeman, R., and Katz, L. 1992. "On the Labor Market Effects of Immigration and Trade." in J. Bhagwati and M. Kosters, eds. Trade and Wages: Levelling Wages Down? Washington: American Enterprise Institute.

Borjas, George J. and Valerie A. Ramey. 1993. Foreign Competition, Market Power and Wage Inequality:Theory and Evidence. National Bureau of Economic Research Working Paper 4556. Cambridge, MA: National Bureau of Economic Research.

Bound, John and George Johnson. 1992. "Changes in the Structure of Wages in the 1980s: An Evaluation of Alternative Explanations." American Economic Review. 82 (June): 371-92.

Bound, John and Johnson, George. 1995. "What Are the Causes of Rising Wage Inequality in the United States?" Federal-Reserve-Bank-of-New-York-Economic-Policy-Review. 1 (January):9-17.

Chiang, Alpha C. 1984. Fundamental Methods of Mathematical Economics, Third Edition. New York: McGraw Hill.

Cooper, Richard N. 1994. Foreign Trade, Wages and Unemployment. Harvard University Department of Economics, Working Paper.

Deardorff, A. and Hakura, D. 1994 "Trade and wages -- what are the questions?" in J. Bhagwati and M. Kosters, eds. Trade and Wages: Levelling Wages Down? Washington: American Enterprise Institute. 
Deardorff, Alan and Staiger, Robert. 1988. "An Interpretation of the Factor Content of Trade." Journal of International Economics. 24 (February): 93-107.

Gandolfo, Giancarlo. 1987. International Economics I: The Pure Theory of International Trade. Berlin: Springer-Verlag.

Goldsmith, James. The Trap. New York: Carroll \& Graf, 1993.

Hamermesh, Daniel. 1986. "The Demand for Labor in the Long Run." in Orly Ashenfelter and Richard Layard, eds. Handbook of Labor Economics. 429-471. Amsterdam: Elsevier Science Publishers.

Johnson, George E. and Frank P. Stafford. "International Competition and Real Wages." in American Economic Association Meetings in Year.

Johnson, Harry G. "Factor Market Distortions and the Shape of the Transformation Curve." Econometrica 34 (1966): 686-698.

Juhn, Chinui, Murphy, Kevin M., and Pierce, Brooks. 1993. "Wage Inequality and the Rise in the Returns to Skill.” Journal of Political Economy. 101(3): 410-42.

Juhn, Chinhui and Murphy, Kevin M. 1995. "Inequality in Labor Market Outcomes: Contrasting the 1980s and Earlier Decades." Federal Reserve Bank of New York: Economic Policy Review. 1: 26-32.

Katz, Lawrence F. and Kevin Murphy. 1992. "Changes in Relative Wages in the United States, 1963-87: Supply and Demand Factors." Quarterly Journal of Economics. 107 (February): 35-78.

Katz, Lawrence F. and Lawrence H. Summers. 1989. "Industry Rents: Evidence and Implications." Brookings Papers on Microeconomic Activity. 209-291.

Krueger, Alan B. 1995. Labor Market Shifts and the Price Puzzle Revisited. Princeton University. Mimeo

Krugman, Paul. 1995a. Technology, Trade and Factor Prices. Stanford University. Mimeo.

Krugman, Paul R. 1995b. “Growing World Trade: Causes and Consequences.” Brookings Papers on Macroeconomic Activity. 1..

Lawrence, Robert Z. 1996. Single World: Divided Nations? The Impact of Trade on OECD Labor Markets. Paris: OECD Development Centre (forthcoming). 
Lawrence, Robert and Evans, Carolyn. 1996. Insights from the Black Box. mimeo.

Lawrence, Robert Z. and Slaughter, Matthew. 1993. "Trade and US Wages in the 1980s: Giant Sucking Sound or Small Hiccup?". Brookings Papers on Economic Activity: Microeconomics. 2: 161-226.

Leamer, Edward. 1995. "A Trade Economist's View of U.S. Wages and Globalization." in Susan Collins, ed. Imports, Exports and the American Worker. Washington DC: Brookings Institution.

Leamer, Edward. 1996. “What's the Use of Factor Contents?" Cambridge, MA: National Bureau of Economic Research Working Paper 5448 (February). Cambridge, MA: National Bureau of Economic Research.

Noguchi, Asahi. 1991. "The Two-Sector General Equilibrium Model: Numerical and Graphical Representations of an Economy." The Mathematica Journal. 1(3): 96-103.

Noguchi, Asahi. 1993. "General Equilibrium Models." in Hal Varian, ed. Economic and Financial Modeling with Mathematica. New York: Springer-Verlag.

Sachs, Jeffrey and Shatz, Howard. 1994. "Trade and Jobs in US Manufacturing." Brookings Papers on Economic Activity. 1: 1994.

Sachs, Jeffey and Schatz, Howard. 1995. "International Trade and Wage Inequality in the United States: Some New Results." In Susan Collins, ed. Imports, Exports, and the American Worker. Washington, D.C.: Brookings Institution.

Slaughter, Matthew J. 1994. "The Impact of Internationalization on U.S. Income Distribution." in Richard O'Brien, ed. Finance and the International Economy 8: The Amex Bank Reivew Prize Essays, 143-158. New York: Oxford University Press.

Thygesen, Niels, Kosai, Yukata, and Lawrence, Robert Z. Globalization and Trilateral Labor Markets A Draft Report to the Trilateral Commission, April 1996.

Welch, Finis. 1970. 'Education in Production." Journal of Political Economy. 78.

Wolfram, Stephen. 1991. Mathematica: A System for Doing Mathematics by Computer, Second Edition. Redwood City, CA: The Advanced Book Program, Addison-Wesley Publishing Co.

World Bank. 1995. Global Economic Prospects and the Developing Countries. The World Bank: Washington, D.C.

Wood, Adrian. 1994. North-South Trade, Employment, and Inequality. Oxford: Clarendon. 
Fig 1 Blue \& White Collar (nonsales) Compensation $(1981=100)$

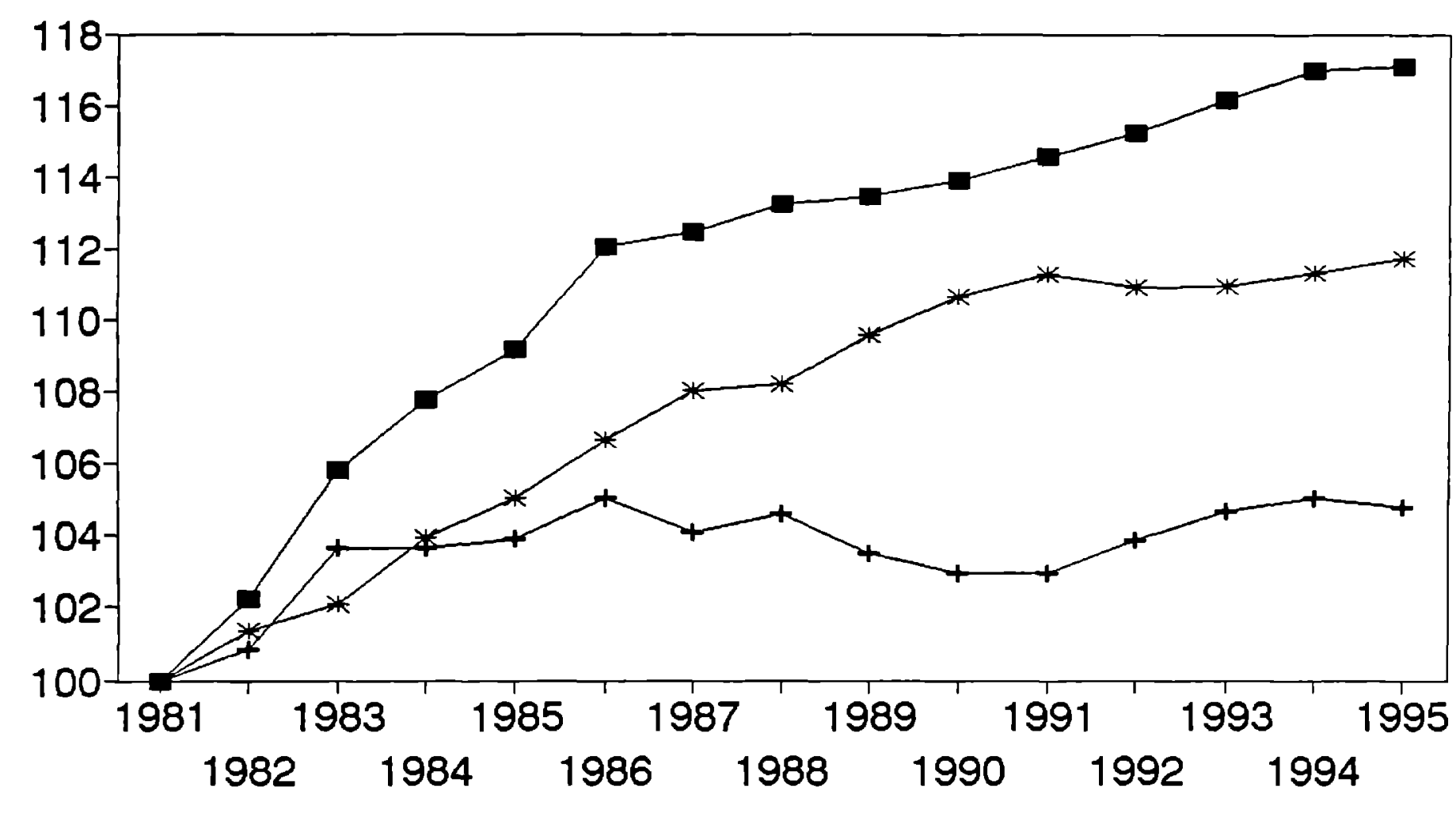

$\rightarrow-$ White/CPI $\rightarrow$ Blue/CPI $*$ White/Blue 
Figure 2

Importable Good

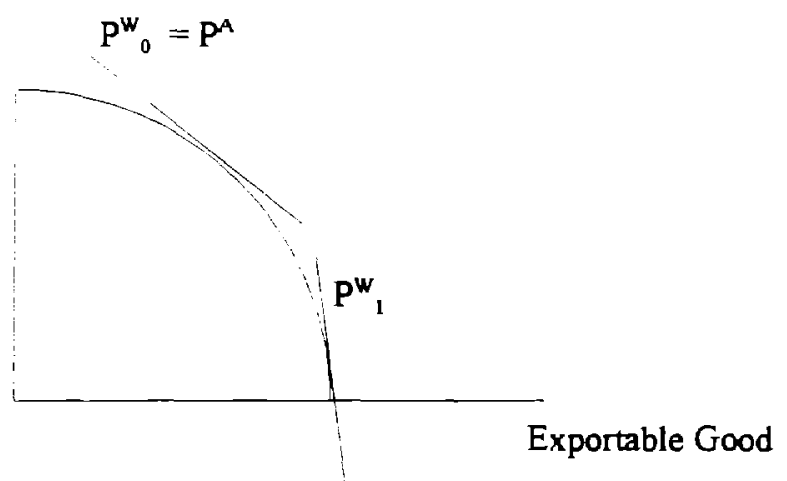




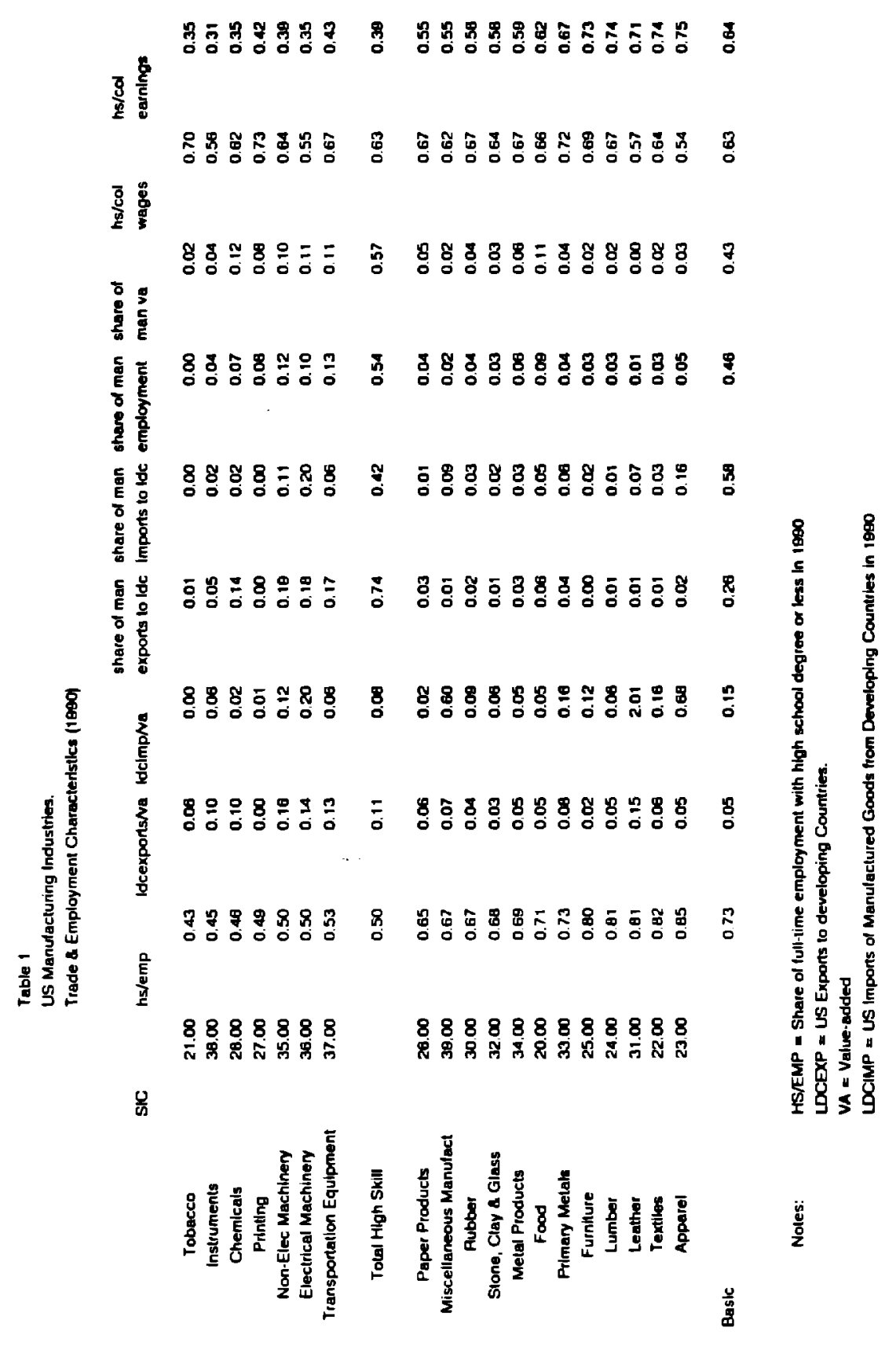


Table 2.

Future Scenario

1990 Actual High Skill Basic Manufactu non-man US Economy

$\begin{array}{llrrrrr}(1) & \text { Value Added(billions) } & 742.05 & 552.45 & 1294.5 & & \\ (2) & \text { Employment(millions) } & 10.18 & 8.68 & 18.86 & 86.17 & 105.03 \\ (3) & \text { Value Add/Emp(thous } & 72.89 & 63.65 & 68.64 & & \\ (4) & \text { High Scool Emp(mill) } & 5.08 & 6.36 & 11.44 & 39.85 & 51.29 \\ (5) & \text { College Emp(mill) } & 5.10 & 2.32 & 7.42 & 46.32 & 53.74 \\ (6) & \text { share hs/emp(4/2) } & 0.50 & 0.73 & 0.61 & 0.46 & 0.49 \\ (7) & \text { ratio hs/col(4)/(5) } & 1.00 & 2.74 & 1.54 & 0.86 & 0.95\end{array}$

Hypothetical

$\begin{array}{llrrrrr}(8) & \text { Value Added } & 1294.50 & 0.00 & 1294.50 & & \\ (9) & \text { Employment(8/3) } & 17.76 & 0.00 & 17.76 & & \\ (10) & \text { High School }(6)^{\star}(9) & 8.86 & 0.00 & 8.86 & 39.85 & 48.71 \\ (11) & \text { College } & 8.90 & 0.00 & 8.90 & 46.32 & 55.22 \\ (12) & \text { ratio hs/col }(10) /(11) & 1.00 & & 1.00 & 0.86 & 0.88\end{array}$

Hypothetical - Actual

$\begin{array}{llllrrr}(13) & \text { employment } & 7.58 & -8.68 & -1.10 & & \\ (14) & \text { high school } & 3.78 & -6.36 & -2.58 & 0.00 & -2.58 \\ (15) & \text { college } & 3.80 & -2.32 & 1.48 & 0.00 & 1.48 \\ (16) & \text { ratio hs/col } & 0.00 & & -0.55 & & -0.072\end{array}$




\begin{tabular}{|c|c|c|c|c|c|c|}
\hline & 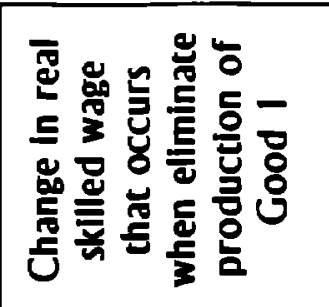 & 今̊ & $\mid \begin{array}{c}0 \\
\stackrel{े}{+} \\
\Phi \\
0 \\
0\end{array}$ & $\mid \begin{array}{l}0 \\
0 \\
0 \\
0 \\
0 \\
0\end{array}$ & 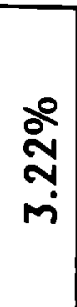 & $\frac{\stackrel{0}{\circ}}{\mathrm{m}}$ \\
\hline & 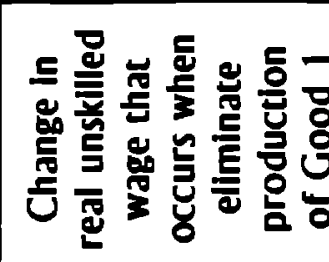 & 商 & $\mid$\begin{tabular}{c}
0 \\
$\frac{0}{2}$ \\
\hdashline \\
$\vdots$
\end{tabular} & $\frac{8}{0}$ & $\begin{array}{c}\frac{0}{\circ} \\
\frac{0}{\infty} \\
+ \\
i\end{array}$ & $\begin{array}{c}0 \\
\stackrel{0}{0} \\
+ \\
+\end{array}$ \\
\hline \multirow{6}{*}{ 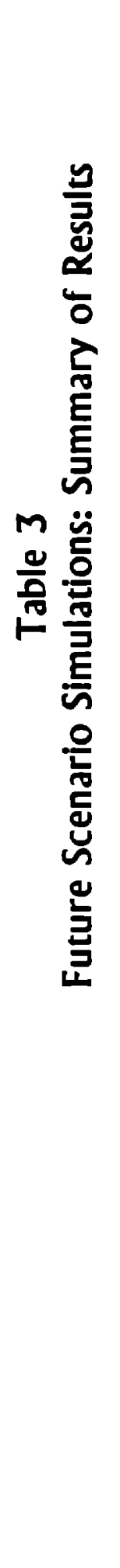 } & 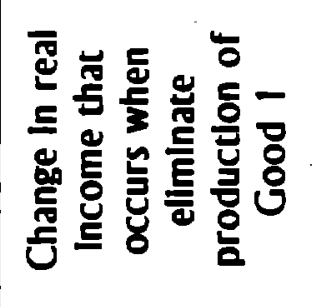 & 윰 & 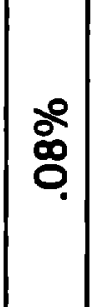 & $\stackrel{\circ}{\stackrel{\circ}{-}}$ & ڤั) & 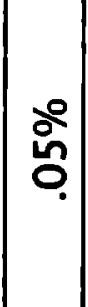 \\
\hline & 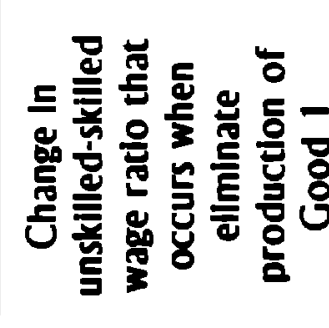 & 商 & $\mid$\begin{tabular}{c}
$\stackrel{\circ}{\grave{\alpha}}$ \\
$\dot{\alpha}$ \\
\hdashline
\end{tabular} & 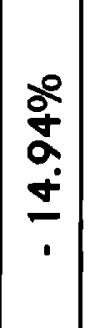 & $\frac{\circ}{\stackrel{2}{r}}$ & 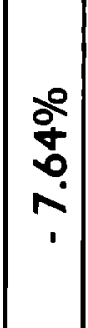 \\
\hline & 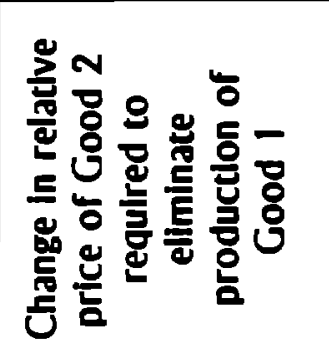 & 产 & $\mid \begin{array}{c}0 \\
\stackrel{0}{0} \\
\dot{+}\end{array}$ & $\begin{array}{c}\circ \\
\stackrel{0}{0} \\
\stackrel{+}{+}\end{array}$ & 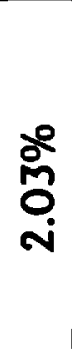 & $\mid \begin{array}{l}0 \\
\stackrel{2}{\alpha} \\
\alpha \\
-\end{array}$ \\
\hline & 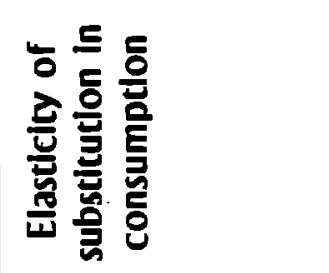 & 8 & 은 & 2 & $\alpha$ & 운 \\
\hline & 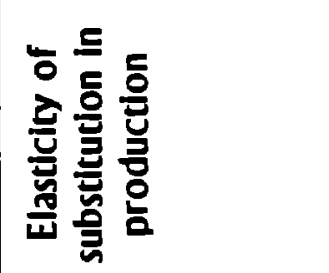 & 8 & 운 & 운 & $\alpha$ & 2 \\
\hline & 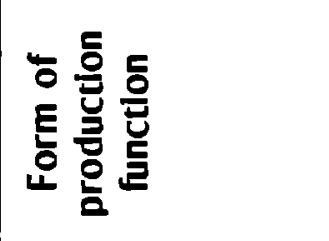 & 害哭 & 岂 & $\tilde{u}$ & $\check{u}$ & $\breve{u}$ \\
\hline
\end{tabular}


Table 4

Future Scenario Simulations: Parameters of the Production Functions

\begin{tabular}{|l|c|c|c|c|c|c|c|c|}
\hline \multicolumn{4}{|c|}{} & \multicolumn{2}{c|}{ Sector 1 } & \multicolumn{2}{c|}{ Sector 2} & \multicolumn{2}{c|}{ Sector 3} \\
\hline $\begin{array}{c}\text { Form of } \\
\text { production } \\
\text { function }\end{array}$ & $\begin{array}{c}\text { Elasticity of } \\
\text { substiution } \\
\text { in production }\end{array}$ & $\begin{array}{c}\text { Elasticity of } \\
\text { substiuution in } \\
\text { consumption }\end{array}$ & $\begin{array}{c}\text { Unskilled } \\
\text { Labor }\end{array}$ & $\begin{array}{l}\text { Skilled } \\
\text { Labor }\end{array}$ & $\begin{array}{l}\text { Unskilled } \\
\text { Labor }\end{array}$ & $\begin{array}{l}\text { Skilled } \\
\text { Labor }\end{array}$ & $\begin{array}{c}\text { Unskilled } \\
\text { Labor }\end{array}$ & $\begin{array}{c}\text { Skilled } \\
\text { Labor }\end{array}$ \\
\hline $\begin{array}{l}\text { Cobb- } \\
\text { Douglas }\end{array}$ & 1.00 & 1.00 & .62190 & .37810 & .37408 & .62592 & .37408 & .62592 \\
\hline CES & .50 & .50 & .81848 & .18152 & .37316 & .62684 & .37316 & .62684 \\
\hline CES & .50 & .99 & .62427 & .37573 & .37407 & .62593 & .37407 & .62593 \\
\hline CES & .99 & .99 & .81848 & .18152 & .37316 & .62684 & .37316 & .62684 \\
\hline CES & .99 & .50 & .62427 & .37573 & .37407 & .62593 & .37407 & .62593 \\
\hline
\end{tabular}

Table 5

Future Scenario Simulations: Parameters of the Utility Function

\begin{tabular}{|l|c|c|c|c|c|}
\hline \multicolumn{2}{|c|}{} & Sector 1 & Sector 2 & Sector 3 \\
\hline $\begin{array}{c}\text { Form of } \\
\text { utility } \\
\text { function }\end{array}$ & $\begin{array}{c}\text { Elasticity of } \\
\text { substitution in } \\
\text { production }\end{array}$ & $\begin{array}{c}\text { Elasticity of } \\
\text { substitution in } \\
\text { consumption }\end{array}$ & $\begin{array}{c}\text { Distribution } \\
\text { Parameter }\end{array}$ & $\begin{array}{c}\text { Distribution } \\
\text { Parameter }\end{array}$ & $\begin{array}{c}\text { Distribution } \\
\text { Parameter }\end{array}$ \\
\hline $\begin{array}{l}\text { Cobb- } \\
\text { Douglas }\end{array}$ & 1.00 & 1.00 & .07 & .10 & .83 \\
\hline CES & .50 & .50 & .01 & .02 & .97 \\
\hline CES & .50 & .99 & .08 & .10 & .82 \\
\hline CES & .99 & .99 & .08 & .10 & .83 \\
\hline CES & .99 & .50 & .01 & .02 & .98 \\
\hline
\end{tabular}




\section{Appendix I \\ The General Equilibrium Model}

The model is a three-sector, two-factor general equilibrium economy. The two factors are skilled and unskilled labor. We assume that the proportion of capital used in production is constant throughout the period and thus do not incorporate it in the simulations. Two of the goods are traded goods, and one is a nontraded good. Of the two traded goods, the good produced in Sector 1 is more unskilled-labor intensive than the good produced in Sector 2 . Good 1 is the importable and is not produced domestically. Thus, we use a model of complete specialization in production.

For most of the simulations, the production and utility functions are of the CES form. One advantage of this form is that we are able to incorporate a range of elasticities of substitution between factors of production or between goods, while still having a functional form that is manipulated fairly easily. To the greatest degree possible, we have chosen the parameters for these functions in accordance with a quantity observable in the data, in ways that are described in the body of the paper. The parameter values for the production and utility functions are as in Table??

The specific functional forms in the model are as follows:

\section{Production}

The production functions are of the CES form.

$$
Q_{i}=A_{i}\left(\alpha\left(a_{L_{i}} L_{i}\right)^{-\rho}+\beta\left(a_{H_{i}} H_{i}\right)^{-\rho}\right)^{(-1 / \rho)}
$$

where $\mathrm{L}_{\mathrm{i}}$ is unskilled labor used in the production of Good $\mathrm{I}$, and $\mathrm{H}_{\mathrm{i}}$ is skilled labor used in production of Good I.

\section{Consumption}

We also assume a CES form for the utility function:

$$
\left.U=\left[\kappa C_{1}^{-\tau}+(1-\kappa-\delta) C_{2}^{-\tau}+\delta C_{3}^{-\tau}\right)\right]^{(-1 / \tau)}
$$


Which implies demand of the following form:

$$
C_{i}=\frac{P_{i}^{\epsilon-1} \kappa^{(\epsilon / \tau)} * Y}{P_{1}^{\epsilon} \kappa^{(\epsilon / \tau)}+P_{2}^{\epsilon}(1-\kappa-\delta)^{(\epsilon / \tau)}+P_{3}^{\epsilon} \delta^{(\epsilon / \tau)}}
$$

where $Y$ is total income, $P_{i}$ is the price of Good $I$, and $\epsilon=\tau /(\tau+1)$.

\section{Wages}

Wages are set so as to equal the marginal product of the factor in Good I times the price of Good I. Wages for a certain type of worker are uniform across the economy.

$$
\begin{aligned}
& W_{L}=P_{i} \frac{\partial X_{i}}{\partial L_{i}} \\
& W_{H}=P_{i} \frac{\partial X_{i}}{\partial H_{i}}
\end{aligned}
$$

\section{Employment}

The endowment of the two types of workers is assumed to be fixed or to exhibit a discrete change once between 1979 and 1990. Wages are set so as to achieve full employment of all workers, which implies:

$$
\begin{aligned}
L_{1}+L_{2}+L_{3} & =\bar{L} \\
H_{1}+H_{2}+H_{3} & =\bar{H}
\end{aligned}
$$

\section{Solution of the Model}

We examine an economy in complete specialization facing constant terms of trade. The methods of solution for equilibrium in these three cases differ and are not described in detail here. Note that for all the trading equilibria, the prices of the two traded goods are taken as exogenous. 